JOURNAL OF SECURITY AND SUSTAINABILITY ISSUES ISSN 2029-7017 print/ISSN 2029-7025 online

2019 December Volume 9 Number 2 http://doi.org/10.9770/jssi.2019.9.2(12)

\title{
Scopus
}

\section{HOW THE CURRENCY CRISIS EFFECTS THE RELATIONSHIP BETWEEN FINANCIAL INFLOWS AND ECONOMIC GROWTH IN ASEAN COUNTRY}

\author{
${ }^{1}$ Muhadjir Anwar, ${ }^{2}$ Effed Darta, ${ }^{3}$ Marlina Widiyanti, ${ }^{4}$ Hendri Soekotjo \\ ${ }^{l}$ Faculty of Economics and Business, Universitas Pembangunan Nasional Veteran Jawa Timur, Surabaya, Indonesia \\ ${ }^{2}$ Faculty of Economics and Business, Universitas Bengkulu, Bengkulu, Indonesia \\ ${ }^{3}$ Faculty of Economics, Universitas Sriwijaya, Palembang, Indonesia \\ ${ }^{4}$ Faculty of Economics and Business, Sekolah Tinggi Ilmu Ekonomi Indonesia, Surabaya, Indonesia

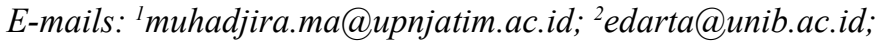 \\ ${ }^{3}$ marlinawidiyanti68@yahoo.co.id; ${ }^{4}$ hendrisoekotjo@stiesia.ac.id
}

Received 18 March 2019; accepted 10 Octobet 2019; published 15 December 2019

\begin{abstract}
The prime aim of the study was to investigate the impact of the financial inflows on the economic growth of ASEAN economies. Meanwhile, the study has examined the moderating role of currency crisis in the relationship between financial inflows and the economic growth of ASEAN countries. The study has employed the panel data methodology to achieve the research objectives. Theoretically and empirically it seems that foreign capital inflows have different possible effects on growth and development performance of an economy. If foreign capital inflows are used in an efficient and productive manner then, they will promote country 's growth performance. If foreign capital inflows are used in unproductive manner then they will not contribute in a long run, their impact on economic development will only for a short run. Furthermore, the financial crisis (currency crisis) also have a significant influence in the attraction of foreign capital inflows. These financial crises effect the flow of foreign capital inflows among the countries. The results suggest that the flow of workers 'remittances in the country has significant positive impact on economic growth. Moreover, the banking and systemic crisis hurt the relationship between REM and EG. Worker remittances are considered as a boon to the countries. It has a positive association with the economic growth and acts a stabilizer during the financial crisis. To ensure the effective inflows of the remittance the government should encourage that remittance should be transferred through formal channels, this can be done by giving cost effective financial services to the remitter, linking the remittance transfer with mobile networks and banks that charge low prices.
\end{abstract}

Keywords: ASEAN countries; financial inflows; economic growth

Reference to this paper should be made as follows: Anwar, M., Darta, E., Marlina Widiyanti, M., Soekotjo, H. 2019. How the currency crisis effects the relationship between financial inflows and economic growth in asean country. Journal of Security and Sustainability Issues 9(2): 517-531. http://doi.org/10.9770/jssi.2019.9.2(12)

JEL Classifications: G1, F23

\section{Background}

Foreign capital inflows play a significant role in the economic growth (EG) of both developing and developed countries (Raza \& Jawaid, 2014; Shuyan, Fabuš, 2019; Tvaronavičienè, 2019; Zeibote et al., 2019; Polyakova et al., 2019). Foreign direct investment increase the productive capacity of the economy, aid, grants, exports of goods and services and the workers' remittances (Bahattab, 2015; Olowa \& Olowa, 2017). Financial aid and grants are considered as a volatile or event-based flow of foreign capital in the economies whereas, foreign direct investment, external debt, workers 'remittances and exports of goods and services are considered as a more sustainable form of foreign capital inflows for developed and developing economies. As a consequence, a large literature has grown, analyzing the cyclical behavior of capital inflows, mostly in emerging economies (Broner \& Ventura, 2016). The existing literature has shown that foreign capital inflows are volatile and pro- 
cyclical and is declines during crisis times. These patterns have more intensity in the countries having different income levels and are also referred to - sudden stops\| that refers to immense collapses in capital inflows that subsequently brings crises (Georgiadis, 2016; Orumwense, 2017).

The recent wave of financial globalization experienced worldwide in recent decades was marked by a significant movement of flow of international capital between countries. These assets are mainly in the form of loans, foreign direct investment (FDI), exports of goods and services (EXP) and remittances by workers(Jake, 2017: Jacqueline $\&$ Paul, 2017). Countries that have opted for their financial sector liberalization were intended to enjoy the effects expected of such a policy. Indeed, by lifting restrictions on incoming and outgoing international capital movements, financial liberalization improves the sharing of risk, the effectiveness of an international allocation of capital and the promotion of financial development and EG. Foreign direct investment, workers remittances external debt and exports of goods and services are the main sources to collect the foreign capital inflows in the economy (Chow, 2017; Sawalha, Elian, \& Suliman, 2016). These all foreign capital inflows play a vital role in economic development of an economy. Empirical studies conclude that these foreign inflows have positive as well as negative impact on economic development and results vary between different countries.

Debates on foreign direct investment, both in academia and in industries, majorly indicate that these flows to a suite of benefits for the host country. FDI was reported as an essential source for the development of economy in the developing countries. FDI not only resulted a reduction in unemployment by creating more employment opportunities but it also provides assistance by technology transfers, accelerates local investment, nurturing human capital and institutions in the host developing countries. The literature has identified two main theories on the basis of endogenous and exogenous growth. These theories have used in the existing literature in order to explain the relationship between FDI and EG.

Most of the innovations and new technologies are created in developed countries. For developing countries, the only chance is to import this technology. Due to financial constraints, the formal transfer of technology seems to be too expensive for these countries. More viable options in terms of cost are international trade and FDI. Past studies suggest the FDI as a main vector for technology transfer. This approach is also justified by the fact that about $70 \%$ of expenditure on research and development in the world are concentrated in a small number of multinational corporations. The increased interest for the externalities of the FDI seems to be explained first of all by the increase in flows to the host country.

The developing countries in general increased measures to attract foreign investors. FDI flows are particularly encouraged by developing countries as perceived as a universal panacea and as a panacea to the problems of transition. The literature considers technology transfer associated with flows of capital as the essential part through which FDI contribute to economic development in the host country (Danakol, Estrin, \& Weitzel, 2017; Jin, García, \& Salomon, 2019). Thus, even without any contribution to the accumulation of capital, the FDI should stimulate technical progress through the transfer of technology and knowledge. If at the theoretical level, the arguments are obvious, the lack of solid empirical evidence remains surprising. Despite the relative consensus in the literature on the fact that foreign enterprises enjoy a direct transfer from the parent company, it has no clear indications about the effects driven at the level of local enterprises. It is theoretically possible that increased competition can compensate any indirect transfer of technology, leading to an overall impact neutral, or even negative.

Remittances by the migrant workers have played a crucial role in nurturing the economic development in the respective countries (Jouini, 2015; Rahma, 2017). Remittances are said to be different from other foreign capital inflow like FDI, loans and aids because these are of stable nature relatively (Bukhari \& Munir, 2016). On the other hand, remittances are found to be in a positive trend when the host economy suffers a recession because of financial crisis, political conflicts or natural disasters etc. as expatriates remit more during crucial time for so that they can support their nations accordingly (Jouini, 2015). Increase in workers 'remittances also resulted in an increase in the private investments. In economic downturn and adversity, such remittances continue to increase and are found to be comparatively less volatile than FDI in those countries that have high marginal propensity to invest. 
The FDI inflow in ASEAN countries is showen figure 1

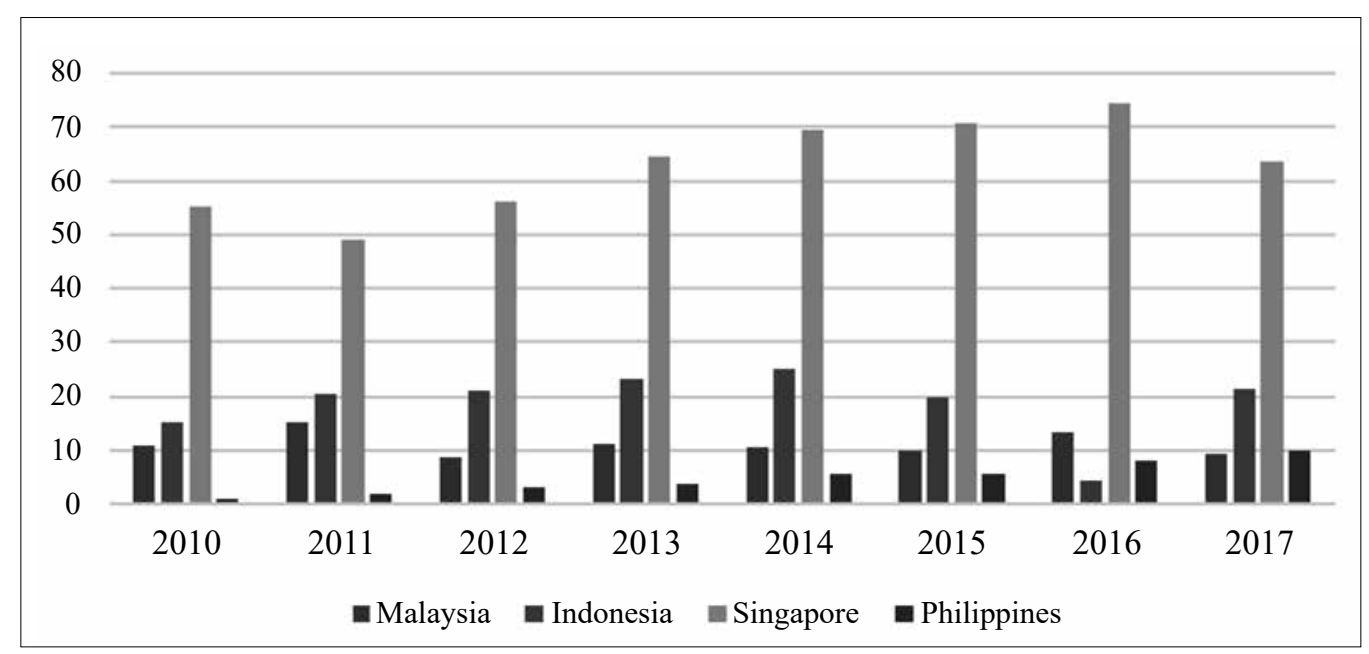

Figure 1. FDI inflows in ASEAN countries

Source: World bank

Foreign capital inflows play a significant role in the EG of developing and developed countries (Rahman, \& Castelli, 2013; Raza \& Jawaid, 2014). Foreign capital has been considered as a key element in the process of economic globalization and integration of the world economy. The flows of foreign capital have been welcomed, to complement domestic financial resources, as a development catalyst. The experience of the newly industrialized or emerging economies has firmed the belief that foreign capital could fill the resource gap of the capital-deficient economies (Bahattab, 2015).

These all foreign capital inflows play a vital role in the economic development of an economy. Empirical studies conclude that these foreign inflows have positive as well as negative impact on economic development and results vary between different countries. Foreign direct investment (FDI) are perceived as a factor of EG, a complement to domestic investment and a source of financing of the current account deficit. FDI contribute the host country in the form of technological externalities, the formation of human capital or have access to foreign markets which lead to long-term EG (Iwasaki \& Tokunaga, 2016; Rusomyo, Junlin \& Mangare, 2017). FDI also resulted a reduction in unemployment by creating more employment opportunities in host economy (Jouini, 2015).

The increase in workers' remittances also resulted in an increase in the private investments (Jongwanich, 2007). Furthermore, remittances are found to be in a positive trend when the host economy suffers a recession because of financial crisis, political conflicts or natural disasters etc. as expatriates remit more during crucial time for so that they can support their families and nations accordingly (Jouini, 2015).

Some empirical studies also found the negative impact of workers 'remittances on EG. The EG may have negative impact of capital inflows (remittances) in the host country which causes the decrease in labor force participation. This type of capital inflows may consider just as transfer of income. Furthermore, this transfer of income may be stressed by severe moral hazard problem. In this regard, the recipients promotes to use alternate way of consumption and the labor market effort reduce accordingly (Raza \& Jawaid, 2014). The migrant's remittances may not be considered as profit driven due to spending on consumption rather than on investment activities (Lim \& Simmons, 2015; Satya \& Kuraesin, 2016). The imports may increase through remittances in the country which further widen the deficit in balance of payment (Jouini, 2015).

Theoretically and empirically it seems that foreign capital inflows have different possible effects on growth and development performance of an economy. If foreign capital inflows are used in an efficient and productive manner then, they will promote country's growth performance. If foreign capital inflows are used in unproduc- 
tive manner then they will not contribute in a long run, their impact on economic development will only for a short run. Furthermore, the financial crisis (currency crisis) also have a significant influence in the attraction of foreign capital inflows. These financial crises effect the flow of foreign capital inflows among the countries. Furthermore, the required external debt for the development projects are also become scare for the developing economies because of the consistent events of financial crisis.

\section{Literature Review}

\subsection{Foreign Debt and EG}

A country's debt can be determined in several ways. There is need to define different types of debt that are linked with an economy. Debt can be private or public. The debts, which are contracted by the government, are called public debts. Alternatively, private entities contracting the debt are referred as private debt. The public debt, which is contracted by the government, can be classified in two debts (internal public debt and external debt). The total of all the debts used by different departments of the State is referred as public debt. Three main factors are linked with public debt such as debt used as interest on previous debt, public spending on various goods/services, debt derived from monetary policies and foreign exchange. Public debt can be referred as the debt between foreign debt and domestic debt. The internal part of the debt is based on the debts, which are contracted with the national lenders by the government.

These types of debts are made through contracts with the internal market specifically through debt securities insurance. Alternatively, the external debt is the total debts, which are contracted with the foreign creditors by the government. The foreign creditors can be from different states, IMF, foreign banks, etc. A country's external debt can be measured in different ways. It was argued by RAZA (2017) that external debt is caused because of international position of investment, gross external debt, and external debt. The total debt instruments of nonresidents and residents are included in the gross foreign debt. This refers to the total amount of foreign debt based on private and public foreign debt. The different between liabilities and financial assets of non-residents and residents is referred as the international investment position. Further, the gross foreign debt excluding the total debt instruments of residents and non-residents is referred as net external debt. Debt has been defined by Turner (2017) to be equal with the country's total liabilities i.e. private and public, with the international creditors. This is referred as the gross external debt.

The definition of external debt is followed by the issues of debt crisis. Following the literature studies, this definition of external debt has been used in this research. The non-compliance of a country's obligations with its international creditors is referred as foreign debt crisis. There can be two forms of debt crisis. In the first form, it occurs when there is need for a country's government to restructure its debt. The second is the type, when the government of a country fails in its obligations. The terms of loan are negotiated in the restructuring of debt. The International Monetary Fund supports in the restructuring of debt as in the case of Greece. It has been claimed by Turner (2017) that partial default is constituted by these. The interest rate is reduced in the restructuring of debt. Further, investors are arrested with illiquid by the restructuring of debt that is not renumbered for years. It becomes a huge cost for the investors in terms of illiquidity. Investors are forced to hold assets having risk and they are given compensation less than the market value. Alternatively, when a country becomes defaulted, this is the extreme crisis. The country becomes unable to comply its obligations with that of creditors. Most of the existing research studies are based on this aspect. Moreover, the economic literature is amid by these two types of circumstances. However, some research studies assume that a country's utilization of huge loan to foreign institutions with the existence of crisis. This study will help in understanding that in any of the previously discussed situation, debt crisis occurs.

In explanation, when a country deals with IMF pertaining to high loan, the country is working on debt restructuring, or there is a default situation, all these refer to debt crisis. To fulfill research objectives, it is crucial to determine the association between external debt and rate of EG. Extensive literature studies exist on the association of these variables. The big recession occurred during 1980-1983 hit almost every economy in 1979 
after the second oil crisis. Serious difficulties were experienced by the indebted economies to managing their debt because the interest rate became very high.

Several studies have worked on understanding the way in which debtor countries were influenced by excessive debt particularly through EG. Irrespective of various research studies available on the association of external debt and EG, there is need for drawing a conclusion. The results of the literature studies vary as per the countries and the situation under which the research has been conducted. Two aspect of casual relation can be used for analyzing the relation among these variables. The first is to analyze through the influence of external debt on the growth of economy and the second is through the influence of EG on foreign debt.

The focus of the previous studies has been on analyzing through the influence of external debt on EG. In this research, the causality relation has been used in this research for external debt and EG. The relevant research studies have been conducted for the associations.

\subsection{Remittances of Workers and $E G$}

A crucial source of income for the emerging economies is the worker's remittances. EG is influenced by remittances due to the stability in contrast to other external capital inflows including FDI, aids, and loan. It was reported that there were $\$ 440$ billion remittances in 2009 , which were made through official channels. There has been a positive trend of remittances over the past two decades. A decline has been revealed in FDI over the last five years in several emerging economies. This is due to continuous increase in remittances of workers.

Some emerging economies have greater remittances as compared with FDI. A crucial role is played by worker's remittances in the development of emerging economies (Jouini, 2015). There is difference in remittances and inflow of foreign capital such as aids, loans, and FDI due to the nature of stability (Siddiqui, \& Anjum, 2013; Bukhari \& Munir, 2016; Hussain et al., 2019). Alternatively, there is positive trend in the remittances when recession i.e. political instability, financial crisis, or disasters prevail in the economy. In this situation, more remittances are expatriated by the workers in other countries to support their nation (Jouini, 2015). It has been argued by some research studies that there is a positive association between EG and remittances of workers (Jouini, 2015). Precisely, investments or consumptions can increase significantly through remittances of workers in the host economies. This reflects the development of country through use of remittances in an efficient way. Poverty can be alleviated through workers' remittances in the emerging countries (Jouini, 2015).

Private investments increase with the increase in worker's remittances. These remittances are not volatile as compared with the FDI in the economies having higher investment marginal propensity during the time of adversity and economic downturn. These kinds of foreign capital inflows are important for the emerging economies as these are likely to influence EG. Serious consequences can be created on EG in the host country. The funds of investors increase directly through capital accumulation by remittances. This also increases human and physical capital in the host country. Alternatively, the credit merit is increased for the local investor that leads to decrease in the country's capital cost. With the decrease of cost, new investment borrowings are resulted. In the similar way, the economic stability can be expedited by remittances in the host country and it becomes less volatile. The risks are reduced in the host country for increasing investment (Raza \& Jawaid, 2014). Capital inflows can created a negative influence on EG in the host economy that leads to decline in the participation of labor force. These inflows can be regarded as income transfer. Moreover, income transfer can be pressurized through the issues of moral hazard. Alternative consumptions ways are promoted through recipients in this regard and effort of labor market declines as well (Raza \& Jawaid, 2014). The overall productivity can be influenced through remittances by increasing the effective investment that changes the financial intermediation of the receiving country.

Remittance can be considered as capital inflow in which the amount of remitter is invested and the pattern of investment is distressed because of the benefits and informational drawbacks as compared with the financial intermediaries, which are local. Remittances may increase the funds in the banking system. In this way, EG can be improved through financial expansion (Williams, 2018). 
The import bills can be paid through sum of foreign exchange reserves. However, a crucial dilemma is the gap in the foreign reserve for the emerging economies. The earning of foreign exchange can be strengthened through remittances particularly for the emerging countries. An opportunity is created by inflows of remittances for reduction in the foreign exchange gap of reserves. Previously, several studies have empirically signified this through use of cross sectional and panel data to define the relation between remittances and EG (Jawaid \& Raza, 2016; Meyer \& Shera, 2017; Sorbi, \& Farrokhnia, 2018). Moreover, fewer research studies have worked on this empirically using time series analysis.

\subsection{Exports and EG}

The purpose of this section is to review the theories of economics, which can assist in explaining the association of growth and trade. Specifically, the main contributions of trade theories and growth theories have been assessed to understand the association, the extent, and causality. The Economic Sciences and economic thought is combined in the growth and trade theories. The importance of trade for generating wealth of Nations was stressed by several economists including David Ricardo, and Adam Smith. It was argued by the economists that for increasing the wealth and welfare of economies, international trade is vital. It was anticipated that different factors act as inducer for growth and some hinder it at the intuitive level. It was considered by Smith that development of human capital and economies of scale are important in contrast to other factors.

The growth and trade theories have common origin in economies and these have been targeted by the scientific developments particularly in the period of postwar. The growth and trade theories are taught using the same methodologies and hypotheses framework in different ways. The trade theories are considered as the microeconomics extension but this is still in the initial stage. The models with which the trade can be studied in the macroeconomics are sought.

The growth theories are considered to the originated from macroeconomics. Unusual and intense efforts are being made to substantial the macroeconomic models in the bases of microeconomics. The growth models, which are most striking, have been developed in a closed economy with no trade relations. Recently, effort is being made to integrate the theories of trade with growth.

The individual contributions of growth and trade theories have been discussed in the next paragraph. The difference in the visions of new theories as compared with the traditional theories with respect to the relation of growth and trade has been analyzed. Further, an overview has been presented for the theoretical concepts about the relation between these variables. There are two classifications of traditional theories of trade, which include classical and neo-classical trade theories. The theoretical relations of the comparative advantages related to trade have been discussed. Previously, the focus of these theories was on the static factors of the benefits as compared with the new trade theories, which highlight dynamics of the benefits. The efficient production allocation is involved in the traditional theories, which focus on equilibrium in the models of trade. The economies involved in trade must have maximization of benefits and trade benefits. The constant scale of production and perfect competition are assumed in these models.

Particularly, there is constant marginal return of a production factor in a classical theory. However, this has become descending in the neo-classical theories. In long term, the equilibrium conditions of these models can be regarded as practically applicable. The trade development because of opening trade and gains of economies being enhanced through use of comparative advantages has been discussed by these theories. Greater allocation of technology can be resulted through liberalization of trade between two countries. Therefore, the high level of production and welfare is resulted.

The comparative advantage theory of Ricardo is the most complete and widespread in view of a classical trade theory. Earlier, Smith had established an absolute advantage theory based on his theory of value and production. According to the theory, the countries earn income and welfare gains to maintain a situation of free trade among themselves. Each country specializes in some measure in the production and exportation of some goods, which 
produces these goods more cheaply in absolute terms as compared of its partners. The exchange of goods through exports allow countries to share the advantages of lower costs of production through absolute advantage that each has or has developed in one sector or another.

In bases similar to those of Smith, but elaborating on the role of labour force as main source of wealth, Ricardo formulated the theory of comparative advantage (Subair, \& Oriogu, 2016; Irwin, 2017). He clarified that it is essential to domestic mobility of labour, which is the primordial and unique production factor. He argued that the necessary adjustments in mobility arise for an economy to obtain the benefits of trade liberalization. Based on this requirement and in the event of balance of commercial accounts, demonstrated that a country, even if you have absolute advantages in all goods produced by him, could have comparative advantages in certain more durable than other free trade conditions. Under these conditions, your trading partner, although devoid of absolute advantages, could have certain comparative advantages. Balistreri (2019) concluded that the gains from trade depend not only on the exchange of goods produced at lower costs, but also use more efficient and globally full production capacities available in the countries. To this end, each country should specialize in property in that it is more efficient, in relative terms, regardless of whether countries that are even more efficient in these same goods. In short, a country even without absolute advantages you can obtain profit and also provide other to its partners in free trade situation, specializing in accordance with the comparative advantages.

Regardless of its simplicity, the classical theory contains a fundamental message that trade induces the specialization process that can become economies more efficient mutually with highest standard of production and consumption. The key to these efficiency gains, which may include some temporary EG lies in the average increase overall productivity of countries. As emphasizes Pawar and Meymandpour (2017), "The simple Ricardo model remains useful for thinking about issues of host nation, such as the effects of technological progress on patterns of specialization and the distribution of gains from trade". The job of the Ricardian model in the analysis of the facts can be very useful, although it requires caution. Absolute differences in size and absolute differences in productivity among economies can limit their specialization based on the advantages of international trade. May also lessen the intensity of this specialization other factors not included in general in the traditional theories, such as transportation costs and imperfections that hinder domestic mobility of production factors, in addition to their own trade barriers. Such factors and asymmetries between the economies may lead to partial specialization, with a tendency to more specialization in certain countries than in others. This is why we find countries producing a wider variety of goods than others. The trend toward specialization is driven by trade and by opening that induces, but these are not sufficient conditions to change the structure of economies.

Neoclassical theories of trade succeed in demonstrating that international trade is the result of separate appropriations of production factors between the countries. The neoclassical theories of trade were originally developed in articles of Zhou, Biswas, and Saunders (2019) formalized definitively by Liang (2017). Designed for the systems of two economies, two goods and two production factors, the Heckscher-Ohlin models were largely extended and generalized to multiple goods and factors, since (Simas, Wood, \& Hertwich, 2015). Neoclassical theories differ from classical theory in the formulation of comparative advantages. In classical theory, such advantages originate from technological differences or, more precisely, of labour productivity. Within the framework of neoclassical theories, resulting from differences in allocation or relative abundance of factors. The neoclassical theories fail to take a production factor, as in the Ricardian model, and they take two or more factors of production. The Cobb-Douglas production function, which enforces inter-sectorial differences and allocation of income distribution in the countries.

\section{Model Specification}

The fundamental objective of the calculation of productivity is to identify the production variation that cannot be attributed to the change in the quantities of inputs. In available literature, the majority of studies used the CobbDouglas production function framework.to analyze the EG in different economies.

In simple words, the Cobb-Douglas function claims that the production capacity of any economy is based on 
the availability of physical capital $(K)$ and labor force $(L)$ of that economy. Furthermore, there are some additional variables (especially technology) which contribute in the production of that economy which represents through $A^{6}$. In this study, we use the following simple form Neo-Classical growth model by using the CobbDouglas production function framework to investigate the relationship between foreign capital inflows and EG:

$$
Y=f(L, K, A)
$$

Where $\mathrm{Y}$ is the real gross domestic product or per capita income, $\mathrm{L}$ is the labor force, $\mathrm{K}$ is the capital stock and $\mathrm{A}$ is the total factor productivity. It is assumed that impact of foreign capital inflows on EG operates through A. This study is using four major items of foreign capital inflows, which play a major role in the economic development namely; foreign direct investment, workers' remittances, external public debt and exports of goods and services. These four items are the main sources of foreign capital inflows for the countries. In the remaining paragraphs of this section, we discuss those studies which use the Cobb-Douglas function to analyze the relationship between FCI and EG.

In past studies, there are several researches use Cobb-Douglas production function framework to analyze the impact of FDI on EG. For Instance, Barrell and Pain (1997) argue that FDI brings diffusion of ideas and provide new and innovated production ways to improve the production process and the goods and services of both MNCs and local firms. Balasubramanyam, Salisu, and Sapsford (1999) analyze the relationship between FDI and EG and conclude that FDI has an important influence over growth performance of the economies. Akinlo (2004) argue that the FDI does not have a significant influence over EG. The results confirm that the attractive foreign direct investment is not a growth enhancing. Marwah and Tavakoli (2004) also use the Cobb Douglas production function framework and confirm the positive impact of FDI on EG.

Choong, Baharumshah, Yusop, and Habibullah (2010) and Hermes and Lensink (2003) claims that the positive externalities of FDI on EG is higher in financially developed economies as compare to less financially developed economies. Anwar and Sun (2011) conclude that the positive influence of FDI on EG is based on the openness of the economy and its real effective exchange rate. Omri and Kahouli (2014) also use the Cobb-Douglas function to analyze the relationship between FDI and EG by using the panel data of 65 countries from the period of 1990-2011. Results conclude the bi-directional causal relationship between FDI and EG. In the recent case of Tunisia, Belloumi (2014) conclude the insignificant relationship between FDI and EG after using the Cobb-Douglas function.

The above discussion confirm that the several recent studies have used the CobbDouglas production function frame work to analyze the relationship between foreign capital inflows and EG. We use the log linear growth model to determine the models of EG. Therefore, the models for empirical estimation based on Cobb-Douglas function is developed as follow

$$
\begin{aligned}
& G D P_{i t}=\alpha_{0}+\alpha_{1} \text { LabF }_{i t}+\alpha_{2} \text { Capital }_{i t}+\alpha_{3} \text { GovEx }_{i t}+\alpha_{4} \text { HCI }_{i t}+\alpha_{5} \text { Inflation }_{i t}
\end{aligned}
$$

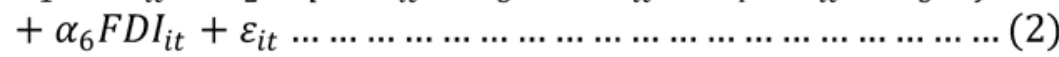

$$
\begin{aligned}
& G D P_{i t}=\alpha_{0}+\alpha_{1} \text { LabF }_{i t}+\alpha_{2} \text { Capital }_{i t}+\alpha_{3} \text { GovEx }_{i t}+\alpha_{4} \text { HCI }_{i t}+\alpha_{5} \text { Inflation }_{i t}
\end{aligned}
$$

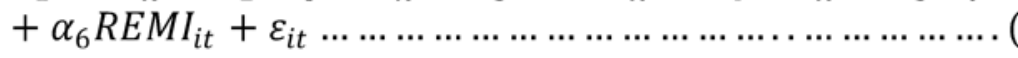

$$
\begin{aligned}
& G D P_{i t}=\alpha_{0}+\alpha_{1} L_{a b F_{i t}}+\alpha_{2} \text { Capital }_{i t}+\alpha_{3} \text { GovEx }_{i t}+\alpha_{4} \text { HCI }_{i t}+\alpha_{5} \text { Inflation }_{i t}
\end{aligned}
$$

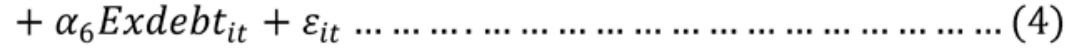

$$
\begin{aligned}
& G D P_{i t}=\alpha_{0}+\alpha_{1} L_{a b F_{i t}}+\alpha_{2} \text { Capital }_{i t}+\alpha_{3} \text { GovEx }_{i t}+\alpha_{4} \text { HCI }_{i t}+\alpha_{5} \text { Inflation }_{i t} \\
& +\alpha_{6} \text { Export }_{i t}+\varepsilon_{i t}
\end{aligned}
$$

Whereas $\varepsilon_{i t}$ is the error term. GDP is a real gross domestic product, $L a b F_{i t}$ is the total labor force and Capital $_{i t}$ represents the capital stock which is measured by real gross fixed capital formation, FDI represents the real foreign direct investment, $R E M I_{i t}$ represents the real amount of workers' remittances, Exdebt $t_{i t}$ represents the real value of external debts and Export it $_{\text {represents the real value of exports of goods and services, GovEx }}$ it 
is a real government consumption expenditure, and $H C I_{i t}$ proxy of human capital which is measured by number of higher education enrollment.

$$
\begin{aligned}
& G D P_{i t}=\alpha_{0}+\alpha_{1} \text { LabF }_{i t}+\alpha_{2} \text { Capital }_{i t}+\alpha_{3} \text { GovEx }_{i t}+\alpha_{4} \text { HCI }_{i t}+\alpha_{5} \text { Inflation }_{i t} \\
& +\alpha_{6} F D I_{i t}+\alpha_{7} C R N C_{i t}+\alpha_{8}(C R N C * F D I)_{i t}+\varepsilon_{i t} \\
& G D P_{i t}=\alpha_{0}+\alpha_{1} \text { LabF }_{i t}+\alpha_{2} \text { Capital }_{i t}+\alpha_{3} \text { GovEx }_{i t}+\alpha_{4} \text { HCI }_{i t}+\alpha_{5} \text { Inflation }_{i t} \\
& +\alpha_{6} R E M I_{i t}+\alpha_{7} C R N C_{i t}+\alpha_{8}(C R N C * R E M I)_{i t}+\varepsilon_{i t} \\
& G D P_{i t}=\alpha_{0}+\alpha_{1} L_{a b F_{i t}}+\alpha_{2} \text { Capital }_{i t}+\alpha_{3} \text { GovEx }_{i t}+\alpha_{4} \text { HCI }_{i t}+\alpha_{5} \text { Inflation }_{i t} \\
& +\alpha_{6} \text { Exdebt }_{i t}+\alpha_{7} C R N C_{i t}+\alpha_{8}(C R N C * E x d e b t)_{i t}+\varepsilon_{i t} \ldots . . \text { (8) } \\
& G D P_{i t}=\alpha_{0}+\alpha_{1} L_{a b F_{i t}}+\alpha_{2} \text { Capital }_{i t}+\alpha_{3} \text { GovEx }_{i t}+\alpha_{4} \text { HCI }_{i t}+\alpha_{5} \text { Inflation }_{i t} \\
& +\alpha_{6} \text { Export }_{i t}+\alpha_{7} \text { CRNC }_{i t}+\alpha_{8}(\text { CRNC } * \text { Export })_{i t}+\varepsilon_{i t} \ldots \ldots \text { (9) }
\end{aligned}
$$

Whereas $(C R N C * F D I)_{i t},(C R N C * R E M I)_{i t}, \alpha_{8}(C R N C * E x d e b t)_{i t}$, and $(C R N C * \text { Export })_{i t}$ are respectively the interaction terms of foreign direct investment, workers' remittances, external debt, and exports of goods and services with currency crises. The model to investigate the impact of foreign capital inflows on EG in the presence of banking crises is estimated by using the following framework

\section{Regression Results}

During the estimation exercise, we conducted a number of tests that included the Redundant Fixed Effects test and Hausman test. For instance, the Redundant Fixed Effects test was conducted to test the hypothesis that time-specific effects are present in the time series and cross section data. This test enables us to determine if the pooled Ordinary Least Squares (OLS) estimation is appropriate or not and whether one should use the FE/ RE estimation. Similarly, the Hausman test was performed to determine if the RE estimates are correct and preferred to the FE and GMM estimates (Basheer et al., 2018; bin Hidthiir et al., 2019). The data of asean countries over the period of 32 years from 1982 to 2017 is gathered from the official forums

The fixed effect regression results of the model 2-8 are explained in the table 1, table 2 and table 3 . The findings of the study are showing consistency with the prior finds. The government expenses and inflation appeared in a negative but significant relationship with saving of ASEAN countries.

Table 1. Regression results of fixed effect estimates (equation 2-5)

\begin{tabular}{|c|c|c|c|c|}
\hline $\begin{array}{c}\text { Dependent Variable: } \\
\text { GDP }\end{array}$ & Model 2 & Model 3 & Model 4 & Model 5 \\
\hline Lab & $0.177^{* * *}$ & $0.135^{* *}$ & $0.089^{* *}$ & $0.213^{* * *}$ \\
\hline Capital & $0.198^{* *}$ & $0.154^{* *}$ & $0.170^{* *}$ & $0.239^{* *}$ \\
\hline GovEx & $-0.254^{* *}$ & $-0.0238^{* *}$ & $-0.243^{*}$ & $-0.321^{*}$ \\
\hline HCI & 0.222 & $0.313^{*}$ & $0.284^{*}$ & $0.244^{*}$ \\
\hline Inflation & $-0.797^{* *}$ & $-0.0488^{*}$ & $-0.633^{*}$ & $-0.293^{*}$ \\
\hline FDI & $0.219^{* *}$ & & & \\
\hline REMI & & $0.231^{* *}$ & & $0.234^{*}$ \\
\hline Exdebt & & & & $\mathbf{0 . 6 1 6}$ \\
\hline Export & & & & \\
\hline $\boldsymbol{R}^{\wedge} \mathbf{2}$ & $\mathbf{0 . 7 4 0}$ & $\mathbf{0 . 5 1 8}$ & & $0.816^{* *}$ \\
\hline
\end{tabular}

The moderating effect of the currency crisis is shown in table 3 . The findings confirm that the currency crisis has significant negative impact on the EG as well it negatively moderates the relationship between key economic indicators and EG. 
Table 2. Regression results of fixed effect estimates (equation 3-9)

\begin{tabular}{|c|c|c|c|c|}
\hline $\begin{array}{c}\text { Dependent Variable: } \\
G D P\end{array}$ & Model 6 & Model 7 & Model 8 & Model 9 \\
\hline Lab & $0.237 * * *$ & 0.135 & 0.0089 & 0.0089 \\
\hline Capital & $0.298^{* *}$ & 0.214 & 0.0170 & 0.0170 \\
\hline GovEx & $-0.354 * *$ & -0.271 & $-0.0243 *$ & $-0.0243 *$ \\
\hline HCI & 0.422 & $0.293 *$ & $0.0284 *$ & $0.0284 *$ \\
\hline Inflation & $-0.297 * *$ & $-0.290 *$ & $-0.0633^{*}$ & $-0.0633 *$ \\
\hline FDI & $0.798 * *$ & & & \\
\hline REMI & & 0.238 & & \\
\hline Exdebt & & & $0.0284 *$ & \\
\hline Export & & & & $0.876^{* *}$ \\
\hline CRNC & $-0.124 *$ & $-0.218 * *$ & $-0.218 * *$ & $-0.218 * * *$ \\
\hline CRNC*FDI & $0.0198 * *$ & & & \\
\hline CRNC*REMI & & -0.0238 & & \\
\hline CRNC*Exdebt & & & $0.0284 *$ & \\
\hline CRNC*Export & & & & $0.876^{* *}$ \\
\hline$R^{\wedge} 2$ & 0.921 & 0.523 & 0.821 & 0.871 \\
\hline
\end{tabular}

Dynamic linear panel data models include $\mathrm{q}$ lags of the dependent variable as independent variables in estimating the relationship of interest. In their generic form, dynamic panel data models are presented as:

$$
Y_{i t}=\sum_{j=1}^{q} \gamma_{j} Y_{i t-j}+X_{i t} \beta_{1}+Z_{i t} \beta_{2}+V_{i}+\varepsilon_{i t} \ldots
$$

Developed by Blundell and Bond (1998), system GMM uses additional moment conditions to serve as an improvement in terms of performance of estimators in the models developed in Arellano and Bond (1991). System GMM estimator can appropriately country-specific unobserved effects in a situation where the lagged dependent variable is included in a model as a regressor. In addition to handling country-specific unobserved effect, system GMM offers a number of advantages over other static and dynamic panel data estimation techniques. For instance, according to Wooldridge (2002) GMM has the capacity to efficiently take good account of twin problems of serial correlation and heteroskedasticity. Moreover, in the view of Baum, Schaffer, and Stillman (2003), GMM has the advantage of ensuring consistency in the parameter estimates even in the presence of arbitrary heteroskedasticity. Finally, the study is not the first to employ panel GMM in estimating convergence. Studies that employed panel GMM include Weeks and Yudong Yao (2003).In the words of Nikoloski (2010), .The general data generating process of system GMM is given by Equation

$$
\begin{aligned}
& Y_{i t}=\alpha Y_{i t-1}+\dddot{x} \beta_{i t}+e_{i t} \ldots \ldots \ldots . \\
& e_{i t}=u_{i t}+v_{i t} \\
& E\left[\mu_{i}\right]=E\left[v_{i t}\right]=E\left[\mu_{i} v_{i t}\right] .
\end{aligned}
$$

In Equation [11], the error term has two orthogonal components - fixed effects, $\mu$, and the idiosyncratic shocks, vit. System GMM estimators overtakes differenced GMM estimator by introducing additional moment condition. The additional moment condition is given by Equation [12].

$$
E\left(\Delta y_{i, t-s}\left[\alpha_{i}+u_{i t}\right]\right)=0
$$

for all values of $i, t$ and $s=1, \ldots \infty$ 


\begin{tabular}{|c|c|c|c|c|}
\hline $\begin{array}{c}\text { Dependent Variable: } \\
G D P\end{array}$ & Model 2 & Model 3 & Model 4 & Model 5 \\
\hline $\operatorname{Lag}(G D P)$ & $0.71 * * *$ & $0.781 * * *$ & $0.371 * * *$ & $0.777 * * *$ \\
\hline Lab & $0.43 *$ & $0.71 * *$ & $0.61 *$ & $0.52 * * *$ \\
\hline Capital & $0.56^{*}$ & 0.73 & $0.83 * *$ & $0.79 * * *$ \\
\hline GovEx & -0.02 & -0.14 & 0.20 & $0.13 * *$ \\
\hline HCI & $0.124 *$ & $0.218^{* *}$ & $0.218^{* *}$ & $0.218 * * *$ \\
\hline Inflation & $-0.482 *$ & $-0.876^{* *}$ & $-0.736 * *$ & $-0.876^{* *}$ \\
\hline FDI & $0.123 * *$ & & & \\
\hline REMI & & 0.318 & & \\
\hline Exdebt & & & $0.214^{*}$ & \\
\hline Export & & & & $0.176^{* *}$ \\
\hline Sargan Test ( $p$ value) & $\begin{array}{c}9.426 \\
(0.632) \\
\end{array}$ & $\begin{array}{l}10.596 \\
(0.645) \\
\end{array}$ & $\begin{array}{r}11.086 \\
(0.610) \\
\end{array}$ & $\begin{array}{l}10.432 \\
(0.721) \\
\end{array}$ \\
\hline AR (1) test & 1.432 & 1.322 & 1.582 & 1.521 \\
\hline AR (1) test & 0.152 & 0.151 & 0.152 & 0.151 \\
\hline
\end{tabular}

Table 3. Regression results of GMM estimates (equation 2-6)

The results reported in table 4 has confirmed that findings of the fixed effect and currency crisis has appeared as significant moderator

Table 4. Regression results of GMM estimates (equation 6-9)

\begin{tabular}{|c|c|c|c|c|}
\hline $\begin{array}{c}\text { Dependent Variable: } \\
G D P\end{array}$ & Model 6 & Model 7 & Model 8 & Model 9 \\
\hline $\operatorname{Lag}(G D P)$ & $0.340 * * *$ & $0.372 * *$ & $0.401 * * *$ & $0.421 * * *$ \\
\hline Lab & $0.712 * *$ & $0.321 * *$ & $0.261 * * *$ & $0.322 * * *$ \\
\hline Capital & $0.456 * * *$ & $0.873 * *$ & $0.323 * *$ & $0.479 * * *$ \\
\hline GovEx & $-0.129 * *$ & $-0.104 * *$ & $-0.210 * *$ & $-0.103 * *$ \\
\hline HCI & $0.124 *$ & $0.218^{* *}$ & $0.218^{* *}$ & $0.218^{* * *}$ \\
\hline Inflation & $0-.482 *$ & $-0.436 * *$ & $-0.471 * *$ & $-0.176^{* *}$ \\
\hline FDI & $0.107 * *$ & & & \\
\hline REMI & & $-0.291 * *$ & & \\
\hline Exdebt & & & $0.204 * *$ & \\
\hline Export & & & & $0.327 * *$ \\
\hline CRNC & $-0.181 *$ & $-0.391 * *$ & $-0.371 * *$ & $-0.201 * * *$ \\
\hline CRNC*FDI & $-0.601 * *$ & & & \\
\hline CRNC*REMI & & -0.478 & & \\
\hline CRNC*Exdebt & & & $-0.320 * *$ & \\
\hline CRNC*Export & & & & $-0.126^{* *}$ \\
\hline Sargan Test ( $p$ value) & $\begin{array}{c}9.426 \\
(0.632)\end{array}$ & $\begin{array}{l}10.596 \\
(0.645)\end{array}$ & $\begin{array}{l}11.086 \\
(0.610)\end{array}$ & $\begin{array}{c}10.432 \\
(0.721)\end{array}$ \\
\hline AR (1) test & -1.432 & -1.322 & -1.582 & -1.521 \\
\hline AR (1) test & 0.152 & 0.151 & 0.152 & 0.151 \\
\hline
\end{tabular}


The results suggest that the exports of the country have significant positive impact on EG. Moreover, the banking and systemic crisis hurt the relationship between EXP and EG. The results suggest that the FDI inflow of the country has significant positive impact on EG. Moreover, the banking and systemic crisis hurt the relationship between FDI and EG. It is recommended that at the time of crisis, government should play the role to minimize the negative impact of crisis by acting as a stabilizer for the foreign investors.

\section{Conclusion}

The results suggest that the flow of workers 'remittances in the country has significant positive impact on EG. Moreover, the banking and systemic crisis hurt the relationship between REM and EG. Worker remittances are considered as a boon to the countries. It has a positive association with the EG and acts a stabilizer during the financial crisis. To ensure the effective inflows of the remittance the government should encourage that remittance should be transferred through formal channels, this can be done by giving cost effective financial services to the remitter, linking the remittance transfer with mobile networks and banks that charge low prices. The remittance transfer through formal channels increases the foreign currency reserves and at the time of financial crisis, these reserves can be used to maintain the macroeconomic stability, to minimize the effect of negative shocks and help to boost the EG. Moreover, during the financial crisis, it also lessens credit constraints faced by the country.

The government authorities should also use the remittance inflows in a productive manner which results in creating employment opportunities. For this, the government should encourage tax exempted projects, establish new business in different sectors, and give incentives on investment, as this will encourage the remitter to invest the money and results in increased remittance inflows. Moreover, the authorities should develop policies that encourage international migration and use the remittances in promoting domestic production.

\section{References}

Akinlo, A. E. (2004). Foreign direct investment and growth in Nigeria: An empirical investigation. Journal of Policy Modeling, 26(5), 627-639. http://doi.org/10.1016/j.jpolmod.2004.04.011

Anwar, S., \& Sun, S. (2011). Financial development, foreign investment and economic growth in Malaysia. Journal of Asian Economics, 22(4), 335-342. http://doi.org/10.1016/j.asieco.2011.04.001

Arellano, M., \& Bond, S. (1991). Some tests of specification for panel data: Monte Carlo evidence and an application to employment equations. The Review of Economic Studies, 58(2), 277-297. http://doi.org/10.2307/2297968

Bahattab, A. S. A. (2015). The impact of foreign capital inflows on economic growth of Yemen: Does institutional factors matter? , Universiti Utara Malaysia.

Balasubramanyam, V. N., Salisu, M., \& Sapsford, D. (1999). Foreign direct investment as an engine of growth. Journal of International Trade \& Economic Development, 8(1), 27-40. http://doi.org/10.12691/jbms-2-2-1

Balistreri, E. J. (2019). International Trade Policy: Insights from a General-equilibrium Approach. Agricultural Policy Review, (1), 4.

Barrell, R., \& Pain, N. (1997). Foreign direct investment, technological change, and economic growth within Europe. The economic journal, 107(445), 1770-1786. https://doi.org/10.1111/j.1468-0297.1997.tb00081.x

Basheer, M. F., Khan, S., Hassan, S. G., \& Shah, M. H. (2018). The Corporate Governance and Interdependence of Investment and Financing Decisions of Non-Financial Firms in Pakistan. The Journal of Social Sciences Research, 316-323.

Baum, C. F., Schaffer, M. E., \& Stillman, S. (2003). Instrumental variables and GMM: Estimation and testing. The Stata Journal, 3(1), $1-31$.

Belloumi, M. (2014). The relationship between trade, FDI and economic growth in Tunisia: An application of the autoregressive distributed lag model. Economic systems, 38(2), 269-287. https://doi.org/10.1016/j.ecosys.2013.09.002

bin Hidthiir, M. H., Basheer, M. F., \& Hassan, S. G. (2019) The Simultaneity of Corporate Financial Decisions Under Different Levels of Managerial Ownership: A Case of Pakistani Listed Firms. Research in World Economy, 10(2). https://doi.org/10.5430/rwe. v10n2p147 
Blundell, R., \& Bond, S. (1998). Initial conditions and moment restrictions in dynamic panel data models. Journal of econometrics, 87(1), 115-143.

Broner, F., \& Ventura, J. (2016). Rethinking the effects of financial globalization. The quarterly journal of economics, 131(3), 1497-1542.

Bukhari, M., \& Munir, K. (2016). Impact of globalization on income inequality in selected Asian countries. https://mpra.ub.unimuenchen.de/74248/1/MPRA_paper_74248.pdf

Choong, C.-K., Baharumshah, A. Z., Yusop, Z., \& Habibullah, M. S. (2010). Private capital flows, stock market and economic growth in developed and developing countries: A comparative analysis. Japan and the World Economy, 22(2), 107-117. https://doi.org/10.1016/j. japwor.2009.07.001

Chow, G. C. (2017). Capital formation and economic growth in China: BRILL. http://www.jstor.org/stable/2118409

Danakol, S. H., Estrin, S., \& Weitzel, U. (2017). Foreign direct investment via M\&A and domestic entrepreneurship: blessing or curse? Small Business Economics, 48(3), 599-612. https://doi.org/10.1007/s11187-016-9792-z

Georgiadis, G. (2016). Determinants of global spillovers from US monetary policy. Journal of International Money and Finance, 67, 41-61. https://www.ecb.europa.eu/pub/pdf/scpwps/ecbwp1854.en.pdf

Hermes, N., \& Lensink, R. (2003). Foreign direct investment, financial development and economic growth. The Journal of Development Studies, 40(1), 142-163. https://doi.org/10.1080/00220380412331293707

Hussain, H.I., Abidin, I.S.Z., Kamarulzaman, R., Shawtari, F.A. (2018). The Impact of State Affiliated Directors on the Capital Structure Speed of Adjustment in an Emerging Market, Polish Journal of Management Studies, 18 (1), 133-148. https://doi.org/10.17512/ pjms.2018.18.1.11

Irwin, D. A. (2017). Ricardo and comparative advantage at 200. Cloth for Wine?, 7. https://voxeu.org/article/ricardo-and-comparativeadvantage- 200

Iwasaki, I., \& Tokunaga, M. (2016). Technology transfer and spillovers from FDI in transition economies: A meta-analysis. Journal of Comparative Economics, 44(4), 1086-1114. https://doi.org/10.1016/j.jce.2016.10.005

Jacqueline, B.R. and J.P. Paul, (2017). Wellbeing research in education: A critical realist perspective. International Journal of Innovation, Creativity and Change, 3(3): 153-172.

Jake, M., 2017. Building the future school. International Journal of Innovation, Creativity and Change, 3(1): 87-96.

Jawaid, S. T., \& Raza, S. A. (2016). Effects of Workers' Remittances and its Volatility on Economic Growth in South Asia. International Migration, 54(2), 50-68. https://doi.org/10.1111/imig.12151

Jin, B., García, F., \& Salomon, R. (2019). Inward foreign direct investment and local firm innovation: The moderating role of technological capabilities. Journal of International Business Studies, 50(5), 847-855.

Jongwanich, J. (2007). Workers'remittances, economic growth and poverty in developing Asia and the Pacific countries: United Nations Publications.

Jouini, J. (2015). Economic growth and remittances in Tunisia: Bi-directional causal links. Journal of Policy Modeling, $37(2), 355-373$. https://doi.org/10.1016/j.jpolmod.2015.01.015

Liang, Y. (2017). A heterodox reconstruction of trade theory The Routledge Handbook of Heterodox Economics (pp. 320-332): Routledge.

Lim, S., \& Simmons, W. O. (2015). Do remittances promote economic growth in the Caribbean Community and Common Market? Journal of economics and business, 77, 42-59. https://doi.org/10.1016/j.jeconbus.2014.09.001

Marwah, K., \& Tavakoli, A. (2004). The effect of foreign capital and imports on economic growth: Further evidence from four Asian countries (1970-1998). Journal of Asian Economics, 15(2), 399-413. https://doi.org/10.1016/j.asieco.2004.02.008

Meyer, D., \& Shera, A. (2017). The impact of remittances on economic growth: An econometric model. EconomiA, 18(2), 147-155.

Nikoloski, Z. (2010). Financial Sector Development and Income Inequality: Is there a Financial Kuznets Curve? Available at SSRN 1703224 . 
Olowa, O. A., \& Olowa, O. W. (2017). Rice Farmer and Capital Formation: A Case Study of Rice Farmer's Credit Cooperative in Itoikin, Ikosi-Ejirin LCDA, Lagos State. International Journal of Sustainable Development \& World Policy, 6(1), 1-8. https://doi. org/10.18488/journal.26/2017.6.1/26.1.1.8

Omri, A., \& Kahouli, B. (2014). Causal relationships between energy consumption, foreign direct investment and economic growth: Fresh evidence from dynamic simultaneous-equations models. Energy Policy, 67, 913-922. https://doi.org/10.2139/ssrn.2643721

Orumwense, J. O. (2017). Implementation of Continuous Auditing for the Public Sector in Nigeria. Journal of Accounting, Business and Finance Research, 1(1), 19-23.

Pawar, P., \& Meymandpour, R. (2017). An Exploration of Enhancing Adoption and Agility in Technological Changes. Journal of Organisation and Human Behaviour, 6(3), 15.

Polyakova, A.G., Akhmetshin, E.M., Pavlyuk, A.V., Meshkova, G.V. 2019. Investment appeal of a region and its impact on investment inflows. Entrepreneurship and Sustainability Issues, 7(2), 1089-1097. http://doi.org/10.9770/jesi.2019.7.2(21)

Rahma, M. M. (2017). Budget Deficit Sustainability of Bangladesh. Asian Development Policy Review, 5(2), $120-130$.

Rahman, W. A., \& Castelli, P. A. (2013). The impact of empathy on leadership effectiveness among business leaders in the United States and Malaysia. International Journal of Economics Business and Management Studies, 2(3), 83-97.

Raza, S. A. (2017). Impact of Foreign Capital Inflows on Economic Growth in the Presence of Currency and Banking Crises. https://pdfs.semanticscholar.org/b899/7d27b3a603461a069789a9c7b021931e7ef9.pdf?_ga=2.186079273.1256593619.15715863421398787887.1523812061

Raza, S. A., \& Jawaid, S. T. (2014). Foreign capital inflows, economic growth and stock market capitalization in Asian countries: an ARDL bound testing approach. Quality \& Quantity, 48(1), 375-385.

Rusomyo, R., Junlin, H., \& Mangare, C. (2017). The Role of Social Networks as Survival Strategies in Agro-Pastoral Communities in Arid And Semi-Arid Lands in Tanzania. Asian Development Policy Review, 5(2), 90-99.

Satya, M. T., \& Kuraesin, A. (2016). Analysis Place Branding as a Local Culture Kampung Naga West Java Indonesia. International Journal of Management and Sustainability, 5(2), 11-16. http://www.conscientiabeam.com/ebooks/2-4thICETSR-466-2015-(6-10).pdf

Sawalha, N. N., Elian, M. I., \& Suliman, A. H. (2016). Foreign capital inflows and economic growth in developed and emerging economies: A comparative analysis. The Journal of Developing Areas, 50(1), 237-256.

Shuyan, L., Fabuš, M. 2019. Study on the spatial distribution of China's Outward Foreign Direct Investment in EU and its influencing factors. Entrepreneurship and Sustainability Issues, 6(3), 1080-1096. http://doi.org/10.9770/jesi.2019.6.3(16)

Siddiqui, K., \& Anjum, M. (2013). Perceptions towards credit card usage: Factor analytic finding from Pakistan. International Journal of Economics Business and Management Studies, 2(3), 128-135.

Simas, M., Wood, R., \& Hertwich, E. (2015). Labor embodied in trade: The role of labor and energy productivity and implications for greenhouse gas emissions. Journal of Industrial Ecology, 19(3), 343-356.

Sorbi, A., \& Farrokhnia, A. (2018). Landslide Hazard Evaluation and Zonation of Karaj-Chalus Road (North of Iran). International Journal of Geography and Geology, 7(2), 35-44. http://doi.org/10.18488/journal.10.2018.72.35.44

Subair, R. E., \& Oriogu, C. D. (2016). Still an Issue: The Use of Electronic Books in University Libraries in Nigeria. American Journal of Social Sciences and Humanities, 1(2), 67-72. http://doi.org/10.20448/journal.801/2016.1.2/801.2.67.72

Turner, A. (2017). Between debt and the devil: Money, credit, and fixing global finance: Princeton University Press.

Tvaronavičienė, M. (2019). Insights into global trends of capital flows' peculiarities: emerging leadership of China. Administratie si Management Public, (32), 6-17. http://doi.org/10.24818/amp/2019.32-01

Weeks, M., \& Yudong Yao, J. (2003). Provincial conditional income convergence in China, 1953-1997: a panel data approach. Econometric Reviews, 22(1), 59-77. https://doi.org/10.1081/ETC-120017974

Williams, K. (2018). Are remittances good for economic growth? The role of political institutions. Applied Economics Letters, 25(1), 56-60. https://doi.org/10.1080/13504851.2017.1293781

Wooldridge, J. M. (2002). Inverse probability weighted M-estimators for sample selection, attrition, and stratification. Portuguese Eco- 
nomic Journal, 1(2), 117-139. https://link.springer.com/article/10.1007/s10258-002-0008-x

Zeibote, Z., Volkova, T., Todorov, K. 2019. The impact of globalization on regional development and competitiveness: cases of selected regions, Insights into Regional Development 1(1): 33-47. https://doi.org/10.9770/ird.2019.1.1(3)

Zhou, L., Biswas, B., \& Saunders, P. J. (2019). Empirical Investigation of the Impact of Multilateral Trade on Income Convergence Across Countries. The Journal of Business Inquiry, 18(2), 68-81.

Muhadjir ANWAR is Associate Professor of Financial Management at Departement of Management in Faculty of Economics and Business, Universitas Pembangunan Nasional Veteran Jawa Timur, Surabaya, Indonesia. Research interests: Corporate Finance, Behavioral Finance, Investment Analysis, Strategic Management, and Small Medium Enterprises (SMEs).

https://orcid.org/0000-0003-0707-4718

Effed DARTA is Associate Professor of Marketing Management at Departemen of Management in Faculty of Economic and Business, University Bengkulu. Research interests: Marketing Management, Consumer Behaviour, Financial Management, and Human Resources Management

https://orcid.org/0000-0002-9414-3840

\section{Marlina WIDIYANTI}

Marlina Widiyanti is Associate Professor of Financial Management and Strategic Management at Departement of Management in Economic Faculty, University of Sriwijaya. Research interests: Finance Management, Strategic Management, Banking Syariah Management, Human Resources, Marketing Management and Public Sector Management.

https://orcid.org/0000-0003-0431-814x

\section{Hendri SOEKOTJO}

Faculty of Economics and Business, Sekolah Tinggi Ilmu Ekonomi Indonesia, Surabaya, Indonesia.

Hendri Soekotjo is Associate Professor of Management at Departement of Management, Faculty of Economics and Business, Sekolah Tinggi Ilmu Ekonomi Indonesia, Surabaya. Research interests: Marketing Management, Strategic Management, Public Finance, and Human Resources.

https://orcid.org/0000-0002-9217-2250

This work is licensed under the Creative Commons Attribution International License (CC BY).

http://creativecommons.org/licenses/by/4.0/ 